\title{
THE EFFECT OF MASS MEDIA ABUSES AS REFLECTED IN DELLILO'S WHITE NOISE
}

\author{
Widya Hairunnisa ${ }^{1}$, Andi Inayah Soraya ${ }^{2}$ Irmawati $^{3}$ \\ hairunnisawidya@gmail.com ${ }^{1}$ \\ Andiinayahsoraya@unhas.ac.id ${ }^{2}$ \\ irmawati17f@student.unhas.ac.id ${ }^{3}$ \\ Hasanuddin Unversity ${ }^{123}$
}

\begin{abstract}
This research intends to elaborate the effect of mass media abuses through Dellilo's White Noise. Therefore, the researchers analyzed how the effect of mass media abuses influence the character through the novel. In analyzing this research, the researchers used genetic structuralism approach as the grand theory and concept of mass media as the supporting theory. Moreover, the writer used qualitative method and descriptive analysis method in analyzing the data. The result of this research is the writers finds there are three effect of mass media abuses such as (1) consumerism, (2) drug abuses, and (3) violence.
\end{abstract}

Keywords: Mass Media, Genetic Structuralism, and White Noise

\section{INTRODUCTION}

Mass media is one form of technological and communicational progress. Through the development of mass media allows information to spread easily in the community. All forms of information can be disseminated easily and quickly so that it affects the perspective, lifestyle and national culture. However, the rise of mass media users can be affected by their behaviors such as anti-social, consumerism and so forth.

According to Mc Quail (2004), Mass communication brought the existence of mass audiences, develop opinions and beliefs through the society, consumer behavior in society, mass politics and other features that are called mass society. Therefore, mass media can be affected by the opinions of society and also impact on consumer behavior.

The influence of the mass media also had an impact on women's social lives. The mass media often presents the image of women who are oppressed and under male domination. Moreover, it also images women as an object that is easily influenced by the mass media. Sharma
(2012) stated that the mass media has an important role in presents women's issues, besides the mass media also harms violence against women one of them is pornography.

Those phenomenon above reflected in a literary work. As literary work is a medium to express the idea of the author by using their depth imagination. According to Welek and Warren (1962: 94) Literature is a social creation using language as the medium to express the idea of the author. Besides contains social norms literature also represents life of a social reality. Based on this definition, the writers understand that literature is a reflection of society, through literary works, an author expresses the problem of life for which the author himself belongs to. One of them are described in the novel.

White Noise is a novel written by Dellilo in 1984 that tells about the social condition of Postmodernism era in America with the using of mass media. In those era all Americans were hypnotized by the development of various forms of mas media such as radio, television, various magazines and any type of advertisements. The researchers focus on 
analyzing the main character of the novel which is Babette that affected by mass media abuses. In this novel, the main character affected by three factors which are consumerism, drug abuses, and violence.

\section{RESEARCH METHOD}

This study uses descriptive qualitative method to analyze the text through the naration, dialogue, and prologue of the novel. Moreover, the writers apply the genetic structuralism approach in explaining the instrinsic and extrinsic elements of literary works. Genetic structuralism emerges to complete the previous theory, the structural theory which focuses on the structure of a literary work. As stated by Castle (2007: 15) in The Blackwell Guide to Literary Theory, the history of literary theory continues to develop as well as theoretical movements where schools, trends, and fashions sometimes interacting and contesting to each other. Therefore, a theory exists to develop the other theory and sometimes they argue with each other. In this case, genetic structuralism was emerged as the reaction to structuralism which only focuses in intrinsic elements of literary works.

This theory tries to fix the weaknesses of structuralism approach by including genetic factors in understanding literary works. Genetic structuralism is also knownas historical structuralism, which considers that literary works should be analyzed from its historical point of view. Goldmann intends to connect the gap between structuralism (intrinsic) and sociological (extrinsic) approaches.

Genetic structuralism is a literary criticism developed by Goldmann. He was a French philosopher and sociologist of Jewish-Romanian origin. The theory was put forward in his book The Hiden God: $a$ Study of Tragic Vision in the Pensees of
Pascal and the Tragedies of Racine, published in French in 1956 (Dosse, 1997: 175).

Goldmann believes that literary works are a structure. According to him, a literary work is not only a stastic structure but also a historical product that reflected constantly in people's lives. This static structure represents the world view of the autohr as Goldmann argues in Milner (1981: 11) a literary work a set of structural homologies between the literary work and the social reality that the author reflected in their work. On the other hand, the individual work of literature and the world vision of the social class to which the author belongs, and on the other, that world vision and the real social life of the certain times. The term 'world vision' here refers to 'the whole complex of ideas, aspirations and feelings which link together the members of a social group (a group which, in most cases, assumes the existence of a social class) and opposes them to the members of other social groups. Such a world view is produced by a collective subject, but may find its most coherent expression in major literature or philosophical text.

\section{THE RESULT OF RESEARCH The Effect of Mass Media Abuses Towards the Main Character}

Mass media is the medium that provided various types of information. People can access any information they need. However, the excessive use of mass media can lead users to addiction. Therefore, in this part, the writers explained the effect of mass media abuses towards the character as reflected in the novel The White Noise written by Delillo.

\section{a. Consumerism}

One effect of mass media abuses is consumerism. Mass media such as television provided various advertisement which contains any type of product such as 
food. In this novel, the main character Babbete faced addiction to consuming food. However, she did not eat the food she just wants to buy it to fulfill her ambition. It can be seen by the following dialogue below:

\section{Data 1:}

"This isn't the lunch I'd planned for myself," Babette said. "I was seriously thinking yogurt and wheat germ."

"Where have we heard that before?"

Denise said.

"Probably right here," Steffie said.

"She keeps buying that stuff."

"But she never eats it," Steffie said.

"Because she thinks if she keeps buying it, she'll have to eat it just to get rid of it. It's like she's trying to trick herself." (Delillo, 1998: 2)

Based on the dialogue above Babette already decided to eat yogurt and wheat germ for her lunch. However, her children always heard about the plan repeatedly. They feel bored with their mother's desire to plan what kind of food she wants to eat. Their mother always buying the same thing but she never eats the kinds of stuff.

Babette keeps buying any food she wants even if she did not eat the food. After buying the kinds of stuff she feels guilty because seeing his food just thrown away. This addiction makes her feel guilty and angry with herself. Sometimes she wants to buy anything she wants, on the other hand, she did not eat the food and finally, she also feels guilty because the food was stale and she must be thrown the food away. It can be seen by the following data below:

\section{Data 2:}

"But she throws it away before she eats it because it goes bad," Denise said. "So then she starts the whole thing all over again."

"Wherever you look," Steffie said, "there it is."
"She feels guilty if she doesn't buy it, she feels guilty if she buys it and doesn't eat it, she feels guilty when she sees it in the fridge, she feels guilty when she throws it away."

"It's like she smokes but she doesn't," Steffie said. (Delillo, 1998: 2)

It is clear from the dialogue above shows that Babette always buys the same thing repeatedly and throw it away because she did not eat the food. Sometimes she feels guilty when she did not buy the food to fulfill her desire but in the other way, she also feels guilty because she spends a lot of money to buy the food and finally she just threw the food away.

Babette loves her yogurt so much. She can eat as much as she wants. She does not care about her body she keeps consuming the food. She will stop to eat yogurt if she skips the wheat germ. As describes by the following quotation below:

\section{Data 3:}

she said. "If I don't eat my yogurt now, I may as well stop buying the stuff forever. Except I think I'll skip the wheat germ."

The brand name was foreign-looking. I picked up the jar of wheat germ and examined the label closely.

Based on the quotation above we can conclude that Babette is one of most people that attaches by the mass media impact. She consuming the food too much. She also affects the advertisements that she was seen on the TV. That is why she picked the jar of wheat germ because she saw the label on the jar.

Besides Babitte's addict with food she also affects by the mass media entertainment. One of the forms of mass media is radio. She always listens to it when she does her activity. This habit describes by following quotation below: 


\section{Data 4:}

Babette was still there, ironing blouses and listening to a call-in show on the radio, a form of entertainment she'd recently become addicted to.

Based on the data shows that Babbete is an addict with the radio as one form of mass media. She always to the radio when she does her daily activity such as ironing her blouses. Radio provides such entertainments show and it makes Babbete addict and wants to listen to the radio always.

\section{b. Drug Abuses}

The second effect of over-consuming mass media is drug abuse. The more people using mass media the more they can feel the impact of the mass media itself. This phenomenon happens to Babette as the main character of the novel. Babette encounters drug abuse. She consumes the drug to make herself relax. Meanwhile, her husband did not know anything about that but her children know and she was going afraid about her mother's habit. Babette can not remember anything when she was consuming the drug. This can be seen by the dialogue below:

\section{Data 5 :}

"What are we going to do about Baba?" she said.

"What do you mean?"

"She can't remember anything."

"Did she ask you whether she's taking medication?"

"No." (Delillo 1998: 32)

Based on the dialogue above Steffie who was Babette's daughter is anxious about her mother's condition. She asks her father how to save Babette from consuming a drug. However, her father does not know about the Babette condition and the drug.

Babette's daughter worried about the condition of her mother. She tells her father about the drug that has been consuming by her mother most of the time. She assumes that Babette addict to the drug. Those drugs named dillar. It is a kind of drug that makes people forget about anything when they using it. Babette's daughter said that that drug is dangerous for her mother's body. This can be seen by the following dialogue below:

\section{Data 6 :}

"I saw the bottle buried in the trash under the kitchen sink. A prescription bottle. It had her name and the name of the medication."

"What is the name of the medication?"

"Dylar. One every three days. Which sounds like it's dangerous or habitforming or whatever." (Delillo 1998: 33)

The dialogue above shows that Steffie finds the bottle of drugs that have been consuming by her mother. Babette always throws the bottle in the trash under the kitchen sink. The drug's names are Dylar. Steffie assumes that this drug is dangerous and can make her mother addict if she consumes it continuously.

Jack who is Babette's husband is worried about his wife. He asks her about the drug names Dylar. Then, Babette explains that she is consuming the drug and she gets those drugs from someone named Mr. Gray. She is one of the test subjects and already working for years. As we can be seen by the following dialogue below:

\section{Data 7:}

"We were to be test subjects in the development of a super experimental and top secret drug, code-name Dylar, that he'd been working on for years. He'd found a Dylar receptor in the human brain and was putting the finishing touches on the tablet itself. But he also told me there were dangers in running tests on a human. I 


\section{1 | JURNAL ILMU BUDAY}

could die. I could live but my brain could die. The left side of my brain could die but the right side could live. This would mean that the left side of my body would live but the right side would die. There were many grim specters. I could walk sideways but not forward. I could not distinguish words from things, so that if someone said 'speeding bullet,' I would fall to the floor and take cover. Mr. Gray wanted me to know the risks. There were releases and other documents for me to sign. The firm had lawyers, priests."

"They let you go ahead, a human test animal." (Delillo, 1998: 85)

It is clear on the data above shows that Dylar is one of the dangerous medicine. Babette becomes the subject of the Dylar test. It is a secret test in the development of a super experimental and top-secret drug. Mr. Gray was the founder of Dylar and it is a kind of drug that makes the user feel like death but their brain does not die. This drug can control the body of the users. Babette should take the risks of this drug and already sign for the documents as the subject test for the secret drug. However, her husband says to her that the test does not make sense. Mr. Gray treats them like a human test animal.

\section{c. Violence}

The last effect of mass media abuses towards the main character is violence. Babette as the subject of the secret drug always interacts with Mr. Gray the founder of Dylar drug. She forces do the sexual arrangements as the results of being the subject test. It is described by the following data below:

\section{Data 8:}

Babette's sexual arrangement with $\mathrm{Mr}$. Gray, our argument over which of us feared death more. (Delillo, 1998: 109)
The data above shows that Jack already knows about Babbete's sexual arrangement with Mr. Gray. Babette is afraid of death that is why she is consuming the Dylar to kill her afraid. In dealing with her feeling she must be consuming the Dylar and to get those drugs she should make sexual arrangements with Mr. Gray.

Jack goes to meet with Mr. Gray. He is angry about the relationship between his wife and Mr.Gray. as the writers explain before, Babette should make love with $\mathrm{Mr}$. Gray to get the Dylar drug. Therefore, she comes to Mr. Gray with her mask. This situation describes the following data below:

Data 9:

I thought, This is the grayish figure of my torment, the man who took my wife. Did she wheel him around the room as he sat on the bed popping pills? Did each lie prone along one side of the bed, reaching an arm down to paddle? Did they make the bed spin with their lovemaking, a froth of pillows and sheets above the small wheels on swivels? Look at him now, glowing in the dark, showing a senile grin.

"I barely forget the times I had in this room," he said, "before I became misplaced. There was a woman in a ski mask, which her name escapes me at the moment. American sex, let me tell you, this is how I learned my English." (Delillo, 1998: 134)

According to the data above, Jack imagines how his wife can sacrifice herself for Mr. Gray to get the Dylar drug. She should do such a sexual arrangement with Mr. Gray to get the drug. The drug makes her can do anything even though she faced the violence from Mr. Gray and she does not care about that. 


\section{2 | JURNAL ILMU BUDAYA}

Volume 8, Nomor 1, Juni 2020

\section{CONCLUSION}

After analyzing the novel entitled White Noise written by Delillo, the writers conclude that mass media can give many impacts on our life. Through the mass media, we can get any information we want to search for. However, the overdosage of using mass media can also give us a negative impact on it.

Based on the novel the writers find that mass media can give a negative impact on the characters in the novel. The effects of mass media depicted in the novel are consumerism. Mass media such as television, radio, magazines, and et cetera provide advertisements and it can hypnotize the consumer to buy the food through the advertisements. This habit can cause the consumer to becomes consumerism. They will buy anything meanwhile they do not need it the most.

The second impact of mass media abuses is drug abuse. By consuming mass media, the consumer will lead people to know about anything one of them is a drug. Based on the writer's analysis, the main character of the novel faced drug abuse where she is consuming Dylar drug to makes herself relax and run away from the death afraid.

The last impact of mass media abuses is violence. People that become consumerism will do anything to get what they want. Moreover, the writers find that the main character in the novel is to deal with the drug that makes herself more comfort from the afraid of death. She is continuously consuming this drug. Therefore, she should have a sexual arrangement with Mr. Gray to get the drug.

\section{REFERENCE}

Castle, Gregory. 2007. The Blackwell Guide to Literary Theory. USA: Blackwell Publishing.
Delillo, Don. 1998. White Noise. New York: Penguin Books. Edited by Mark Osteen.

Dosse, Francois. 1997. History of Structuralism. Translated by Deborah Glassman. London: University of Minnesota Press Volume I: The Rising Sign, 19451966

McQuail, Denis, ed. McQuail's Reader in Mass Communication Theory. London: SAGE Publications Ltd, 2004.

Milner, andrew. 1981. JOHN MILTON AND THE ENGLISH REVOLUTION: A Study in the Sociology of Literature. USA: Barnes and Nobel Books.

Sharma, Arpita. "Portrayal of Women in Mass Media". Media Watch 4:1(2012): 2.

Wellek, Rene and Warren Austin. 1962. The Theory of Literature. New York: A Harvest Book Harcourt, Brace \& World, Inc. 